\title{
FORECASTING PRICES OF BROILER CHICKENS USING THE CREEPING TREND
}

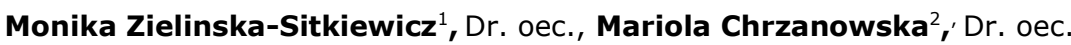 \\ 1,2 Warsaw University of Life Sciences
}

\begin{abstract}
The article raises the issue of forecasting prices of broiler chickens. The forecasts were generated on a set of the weekly time series of mentioned prices in the 2011-2017 period. The forecasting methods which were used in this research are adaptive methods: simple random walk model and creeping trend with fixed segments of linear trends equal 5, 7, 9 and 11 periods. The accuracy of forecasts was verified in retrospect by preparing forecast in the past, forecasting errors and graphical analysis. Both the crawling trend model and the random walk model with greater weight take into account observations closer to the forecasted values, which worked well in the case of fairly large distortions of random variations in a series of purchase prices for broiler chickens. Reducing the length of the segment in case of large random fluctuations and breakdowns of the trend allows to obtain smaller forecast errors.
\end{abstract}

Key words: forecasting, creeping trend, broiler chickens.

JEL code: Q11, Q13, C51, C53

\section{Introduction}

The accurate prediction of economic phenomena is very important from the point of view of making different types of decisions. The quality of the forecast determines whether decisions based on the prediction process will allow the business entities to develop. In the case of agriculture, forecasting is a necessary element of efficient farm management. Early information on the level of prices allows to properly plan work for farmers, but also allows planning the purchase, storage and processing of agricultural production to entities associated with the agricultural-food sector. On a macro scale, it provides the basis for making the right decisions regarding the adaptation of appropriate regulations for agricultural markets or the shaping of agricultural policy. The issues of price forecasting of the selected agricultural products were dealt with, among others, by Dudek (2005), Borkowski (2009), Lira (2011), Hamulczuk and Stanko (2009, 2011), Tluczak (2011) and Hamulczuk et al. (2012, 2013).

From many models that allow forecasting of economy phenomena, adaptive models gain more and more importance. Their high flexibility and adaptability in the case of irregular changes in the direction or speed of the trend or distortions in periodic fluctuations make adaptive models a convenient tool for short-term economic forecasts (Zelias et al., 2003).

The aim of the article is to determine forecasts of extinct prices of broiler chickens using the random walk model (naïve method) and creeping trend models with fixed segments of linear trends equal 5, 7, 9 and 11 periods and assessing the accuracy of forecasts based on ex post error analysis. This will allow to answer the question: which approach allows to achieve the minimum values of forecast errors. The study used average weekly prices of broiler chickens expressed in $\mathrm{PLN} / \mathrm{kg}$, quoted from January 2011 to December 2017. The data comes from the archive of cenyrolnicze.pl website. In order to eliminate the impact of inflation, nominal buying-in prices were converted into real prices, using monthly core inflation indicators (previous month $=100$ ), published by the National Bank of Poland (NBP).

The production of poultry, especially chickens, has been developing very dynamically in Poland in recent years. The high price competitiveness combined with the quality of production and the growing global demand for cheap source of animal protein caused that in 2016 Poland became the largest manufacturer of poultry in the European Union (14\%). According to the National Chamber of Feed and Poultry Producers, in terms of growth dynamics of poultry meat production, Poland 
was the undisputed leader in 2012-2016 with the increasing production per annum by an average of two-digit percentages. What is more, while in Poland production continued to grow continuously, there were declines in other large producer countries. The analyses of PKO Polish Bank of the poultry production sector indicate that high efficiency results from the still significant access to relatively cheap feed and skilled labour, favourable to the regulatory environment, a strong level of concentration and the integration of production. In addition, strongly growing exports are a key factor in the development of the poultry industry in Poland in the last decade. In 2010-2016, the average annual growth rate of foreign sales amounted to $16.4 \%$. In 2016, exports reached a high volume of 1.023 million tons ( $+20.5 \% \mathrm{y} / \mathrm{y}$ ) (Fig.1). The European Union is the main recipient of poultry from Poland (76\%); however, in recent years, exports to non-EU countries has also gained considerable importance, mainly to Asia and Ukraine (Dziwulski, 2017).

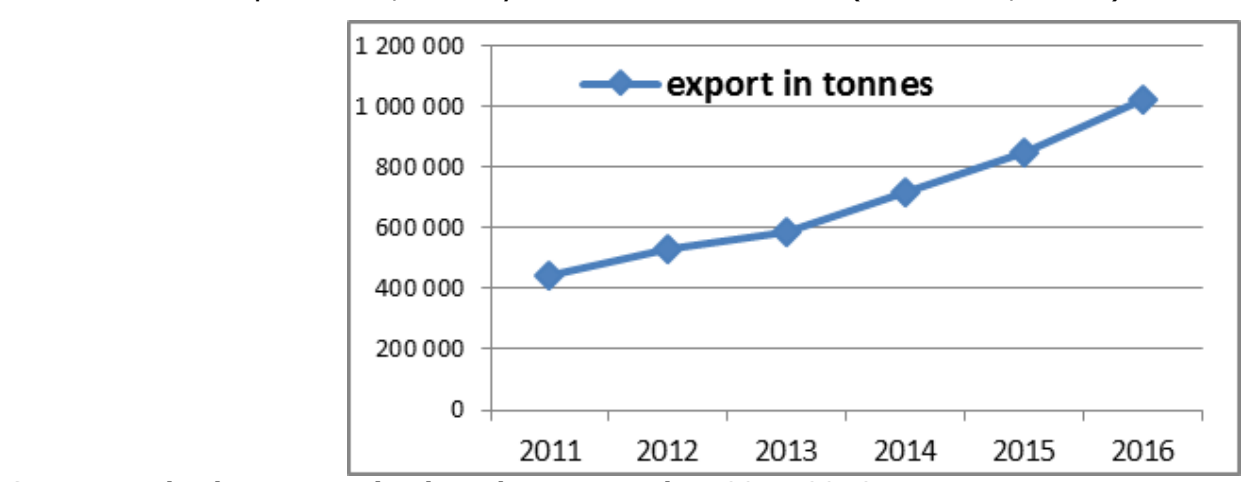

Source: author's presentation based on MARD ${ }^{1}$ data 2011-2016

Fig. 1. Polish export volume of poultry meat in tons

However, 2017 brought about a weakening of the pace of poultry production growth, which was the result of the spread of the bird flu epidemic across the country. As a consequence of these events, there were significant restrictions on the export of poultry meat. Despite this, during the first nine months of 2017, $10 \%$ more poultry meat and offal was exported from Poland than in the same period of 2016, and meat and offal production increased by $8 \%$. In 2017, about $60 \%$ of the domestic production of poultry meat was intended for the needs of the internal market. The consumption of this type of meat in 2017 amounted to around $30 \mathrm{~kg} /$ person, which is one of the highest values in Europe where the average consumption of poultry is around 23 kilograms. For comparison, four years earlier it was maintained in Poland at the level of $26.5 \mathrm{~kg} /$ person. This increase in consumption is the result of both changes in the dietary preferences of consumers, as well as favourable relations between the price of poultry and red meat (Dziwulski, 2017).

\section{Purchase prices of broiler chickens in 2011-2017 - selected information}

The purchase prices of broiler chickens in 2011 remained significantly below the production costs and this has resulted in the resignation of breeding by many breeders. The average weekly purchase prices was $3.78 \mathrm{PLN} / \mathrm{kg}$, with a minimum level of $3.15 \mathrm{PLN} / \mathrm{kg}$, and a maximum of 4.21 $\mathrm{PLN} / \mathrm{kg}$. In 2012, a high growth rate of production was noted, which was related to the increased demand for poultry meat due to high prices of red meat, i.e. beef and pork. The average weekly minimum price for broiler purchase was $3.39 \mathrm{PLN} / \mathrm{kg}$, and the maximum price was $4.38 \mathrm{PLN} / \mathrm{kg}$. The average weekly price of chickens in 2013 amounted to $3.91 \mathrm{PLN} / \mathrm{kg}$ and was $1 \%$ higher than the average for 2012 (Table 1). High purchase prices were maintained with the increasing production and growing exports, but relatively expensive fodder (Fig. 2.).

${ }^{1}$ Ministry of Agriculture and Rural Development 


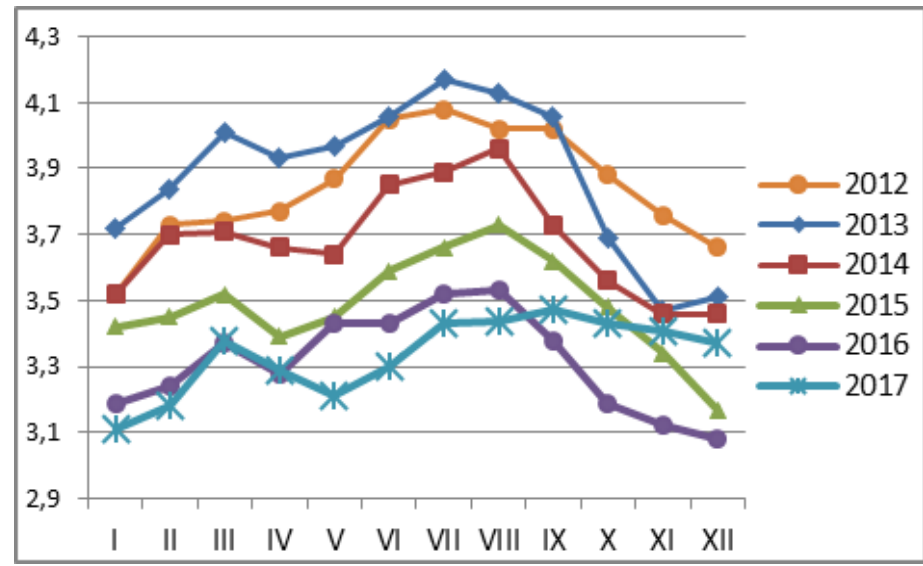

Source: author's presentation based on MARD data 2012-2017

Fig. 2. Average monthly purchase prices of broiler chickens in PLN/ kg

In 2014, the profitability of chicken production increased year-to-year, despite lower purchase prices (weekly average $3.73 \mathrm{PLN} / \mathrm{kg}$ ), as prices paid to producers for slaughterhouse raw material were slower to drop than the prices of industrial feeds. The lower purchase prices of broiler chicken in 2015 than last year were the result of a further increase in domestic production, reduction of red meat prices and lower prices of chickens on the EU market than last year. In 2016, there was another decline in the price of poultry in the country (Fig. 2.). Prices of broiler chickens in Poland at the end of the year were the lowest in the EU. In the week from 28 November to 5 December 2016, the price in Poland was 457.1 PLN/100 kg and it represented only $58.9 \%$ of the average EU price $(776.02 \mathrm{PLN} / 100 \mathrm{~kg}$ ). Since the beginning of 2017 , the purchase prices of broiler chickens have remained at a low level (avian flu, export restrictions). Moreover, after a nearly $13 \%$ increase in production in 2016 (Institute of Agricultural and Food Economics data), in 2017, its apparent slowdown up to $8 \%$ was observed. It is worth noting that in the fourth quarter of 2017 , when a seasonal drop in prices is usually observed, purchase prices of broiler chickens remained stable. This was favoured, among others, by the increased import demand from EU contractors, resulting from smaller supplies from outside the EU and the ban on imports of poultry from Brazil (the world's largest exporter of this type of meat and the largest supplier to the Chinese market) due to the corruption scandal and information on the sale of rotten meat and meat contaminated with salmonella by major production companies in this country.

\section{Factors affecting the level of purchase prices:}

According to the Agricultural Market Agency (ARR), the most important factors determining the purchase prices of broiler chicken include:

\section{- production of poultry livestock in the world}

Foreign Agricultural Service/USDA forecast that global production will grow by 1 percent in 2018 to 91.3 million tons, primarily from gains in the United States, Brazil, India, and the European Union (Fig. 3.). The USA and Brazilian expansion is driven by higher exports while the European Union and India are due to slow but steady growth in domestic demand. China's production is forecast down 5 percent in 2018 for a third year in a row. China continues to be constrained by highly pathogenic avian influenza (HPAI), the limited availability of genetics, a saturated market, weak prices, and soft demand (Livestock and Poultry, 2017). 


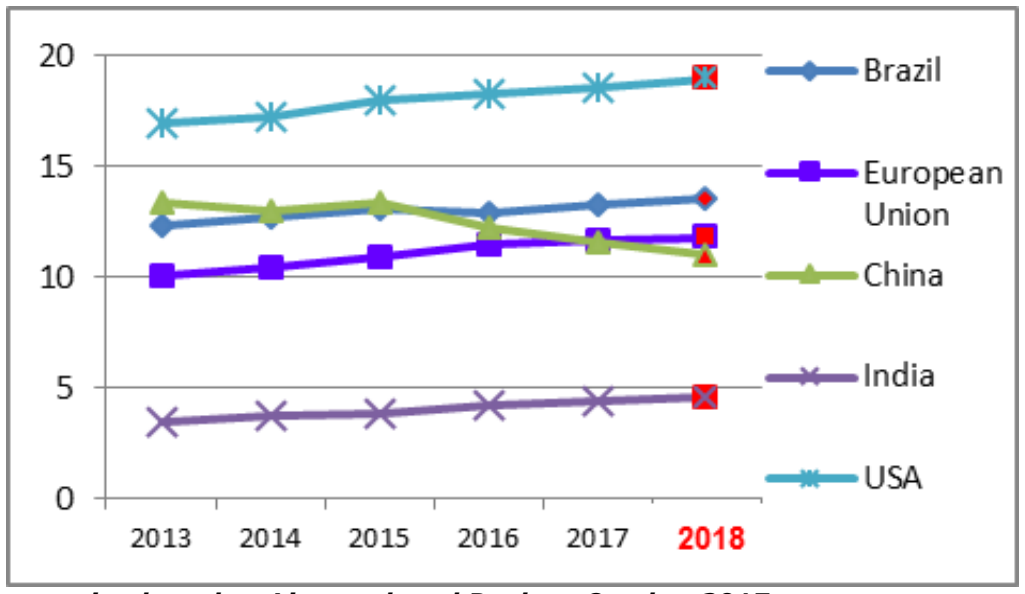

Source: author's presentation based on Livestock and Poultry, October 2017

Fig. 3. Broiler Meat Trade - selected countries in 1.000 metric tons

\section{- production of poultry livestock in the EU}

The European Union is the fourth largest producer of poultry in the world - after the United States, Brazil and China. The EC forecasts show that in 2018 the EU production will increase by $1.2 \%$ to 14.86 million tons, and export by $2.5 \%$ to 1.56 million tons. Moreover, the community is also the third exporter of poultry meat, and at the same time is at the forefront of global importers taking the fourth place (after Japan, Saudi Arabia and Mexico). The expected slowdown in the growth rate of poultry meat production is primarily the result of forecasts of the EU export growing much slower, due to strong competition on foreign markets from the Brazilian and American suppliers, as well as due to outbreaks of avian flu in Europe and restrictions introduced by non-EU countries in import from the EU. The increase in production also slows down the scale of internal consumption growth resulting from the saturation of the EU market, which is lower than in previous years.

\section{- production and purchase of poultry livestock in Poland}

The domestic poultry market has been characterized by a significant dynamics of production growth for years, which is mainly due to the growing foreign sales. The total poultry production in Poland in 2016 reached 3.2 million tons, and its growth rate amounted to $13 \%$. The production of broiler chickens amounted to 2.7 million tones (Fig. 4.), $19 \%$ more, and turkeys - 460 thousand tons, $2 \%$ more.

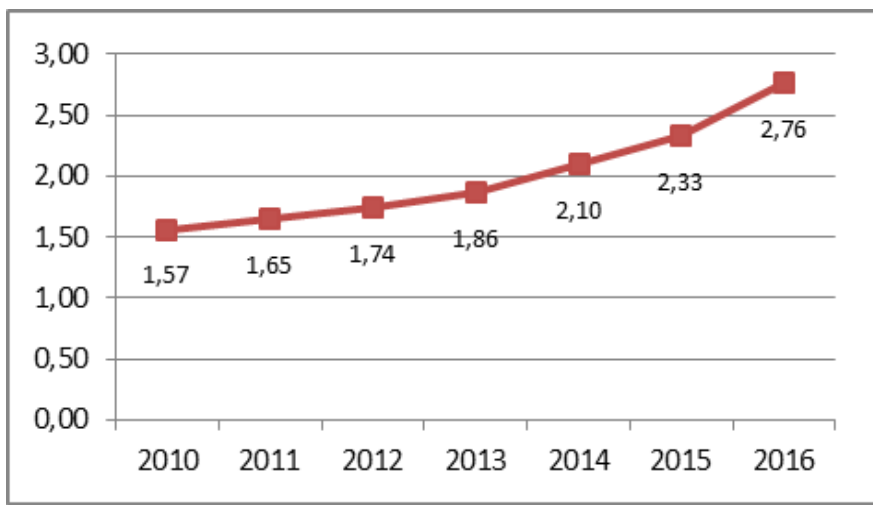

Source: author's presentation based on Institute of Agricultural and Food Economics data

Fig. 4. Poultry production (broiler chickens) in Poland in million tons 
In 2017, poultry production continued to grow and amounted to approx. 3.46 million tons. The slowdown in pace of poultry production growth in 2017 was due to the limited possibilities of increasing export and the low profitability of poultry slaughtering, similar to the limit values.

\section{- foreign trade}

About eighty percent of Polish export goes to European Union countries. The potential of this direction is naturally exhausting. In 2016, over 1.2 million tons of poultry was sold abroad - $19 \%$ more than in 2015. The increase in sales to foreign markets in 2016 resulted mainly from the price and quality competitiveness of Polish poultry in relation to the offer of other EU exporters. At the end of 2016, there were outbreaks of avian flu in the country, which resulted in some countries introducing restrictions on the import of poultry assortments from the whole area or from some regions of Poland. These constraints contributed to the slowdown in the growth rate of exports in 2017. In the first five months of 2017, 525 thousand tons of poultry assortment were exported from Poland, $7 \%$ more than the year before. During this period, 405 thousand tons of chicken meat were exported, $13 \%$ more than the year before, and 78 thousand tons of turkey meat, $15 \%$ less than the year before. It is expected that throughout 2017, export growth rate will be around $12 \%$, so it will be slower than in 2016 and 2015 . The final results of domestic poultry export in 2017 will depend on, among others, from restoring the possibility of selling Polish poultry to the markets of third countries that have introduced restrictions on imports from Poland. Major markets within the EU are the United Kingdom, Germany, France, the Netherlands, and the Czech Republic. Hong Kong, China, and Ukraine are the main markets outside of the EU. The Polish poultry industry is highly integrated and export oriented. Although the majority of exports are directed to the internal EU market, the industry and GOP is trying to open new market opportunities, including U.S. market access (Annual Poultry, 2017).

Imports of poultry meat mostly consist of chicken and turkey cuts from Germany, Slovakia, and the UK. In 2016, it amounted to 139 thousand tons and was $16 \%$ larger than in the previous year. In 2017 , a further $3 \%$ increase in imports of poultry was predicted.

\section{- consumption}

In 2016, retail prices of poultry meat were $2.3 \%$ lower than in 2015, which was conducive to an increase in its consumption. According to the IERiGŻ - PIB estimate, consumption of poultry meat in Poland in 2016 amounted to $29.5 \mathrm{~kg}$ per capita and was $2.4 \mathrm{~kg}$ (9\%) higher than in 2015. It is expected that throughout 2017, its consumption may increase up to $30.5 \mathrm{~kg}$ per capita, due to further reduction of retail prices of poultry.

Poultry meat remains the cheapest animal protein on the Polish market, which stimulates demand. Since 2013, poultry meat retail prices have trended downward. Although Polish consumers continue to prefer pork, with annual per capita consumption at 41 kilograms, poultry meat is perceived as a more healthful and less expensive alternative. Post forecasts that 2018 poultry consumption will increase by two percent because of higher production and lower retail prices. Poultry meat constitutes 38 percent of meat consumed in Poland, compared to 53 percent for pork and only three percent for beef. 


\section{Description methods}

\section{The study used two forecasting methods.}

One of the simplest and yet most important models in time series forecasting is the random walk model. This model assumes that in each period the variable takes a random step away from its previous value, and the steps are independently and identically distributed in size. At period $t$, the $k$-step-ahead forecast that the random walk model (where the distribution of step sizes has zero mean) gives for the variable $Y$ is:

$$
\hat{y}_{t+k}=y_{t}
$$

In others words, it predicts that all future values will equal the last observed value (Nau, 2014).

The creeping trend model is interesting and useful for the short-term prediction method from a wide range of adaptive models, in other words, models adjusting to the output $Y$ series. In comparison to the moving average models and exponential smoothing, the creeping trend model is much more difficult to implement. Its advantage is the forecasting of series, which are characterized by high irregularity or slumps of the trend. This method was presented by Z. Hellwig in 1967 and relies on estimating the trend value in each predefined fragment of the series by means of adjusted linear trends, and then extrapolating the creeping trend thus obtained using harmonic weights.

For a given time series $y_{1}, \ldots, y_{n}$ and the smoothing constant $k<n$ determined by the prognosis, the $n-k+1$ parameters of sectional forms are estimated:

$$
\begin{gathered}
\hat{y}_{t j}=a_{0 j}+a_{1 j} t \\
(j=1, \ldots, n-k+1, \quad t=j, \ldots, j+k-1)
\end{gathered}
$$

where:

$k$ - smoothing constant is the number of cases for each partial trend

$j$ - number of partial trend equation

$\hat{y}_{t j}$ - determined smoothed value. For a given $t$ from 2 to $n-1$, there is a set of approximants calculated from the partial trends equations.

$a_{0 j}, a_{1 j}$ - estimated values of the partial trends equations.

The creeping trend is computed according to the formula:

$$
\hat{y}_{t}=b_{0 t}+b_{1 t} t
$$

and the following calculation can be used to obtain the estimates:

$$
\begin{aligned}
& b_{0 t}=\frac{1}{m} \sum_{j=j_{0}}^{j_{0}+m-1} a_{0 j} \\
& b_{l t}=\frac{1}{m} \sum_{j=j_{0}}^{j_{0}+m-1} a_{1 j}
\end{aligned}
$$

where:

$\hat{y}_{t}$ - determined smoothed value (fitted value) for period $t$

$b_{0 t}, b_{1 t}$ - estimated values being mean values of estimates of the partial trends equations for $t \in\langle j, j+k-1\rangle$

$m$ - number of the partial trends equations for $t \in\langle j, j+k-l\rangle$ 
$j_{0}-$ number of the first partial trend equation for $t \in\langle j, j+k-1\rangle$

By combining successive points $\left(t, \hat{y}_{t}\right)$, a development trend of the time series is obtained in the segment form, the so-called creeping trend. Let us note that the series of predictions is exactly the same length as the output series of real observations. To make a forecast, an algorithm based on harmonic weights should be used (Zelias et al., 2003).

\section{Results of the study}

Average weekly purchase prices of broiler chickens from the first week of January 2011 ( $t=1$ for 03.01-09.01.2011) until the last week of December 2017 ( $t=365$ for 25.12-31.12.2017) are shown in Figure 1. The average price of one kilogram of broilers in the analysed seven years was 3.64 PLN, with a minimum price of 2.81 PLN recorded at the turn of November and December 2016 and a maximum price of 4.45 PLN from July 2013. Chicken purchase prices were usually the lowest in the fourth quarter of each year (in November and December), and the highest in the third quarter (in July or August). In Figure 1, one can notice a certain tendency regarding the purchase prices of broiler chicken in particular years. Mostly at the beginning of the year, prices were relatively low. In March, they were higher on average by around $6 \%$ compared to the price in January. In April, the downward trend followed and from May the trend changed direction to the growing, and each year the prices reached their maximum in July and August. With the approaching end of the year, the prices of chicken were mostly decreasing. The year 2017 was the exception, when the prices in November and December were at a similar level as in July and August.

The Table 1 contains the results of the basic descriptive statistics calculated for weekly buyingin prices of broiler chickens for years 2011-2017. They confirm that the highest chicken purchase prices, with the highest observed variability, were registered in 2013, and the lowest in 2016 and 2017.

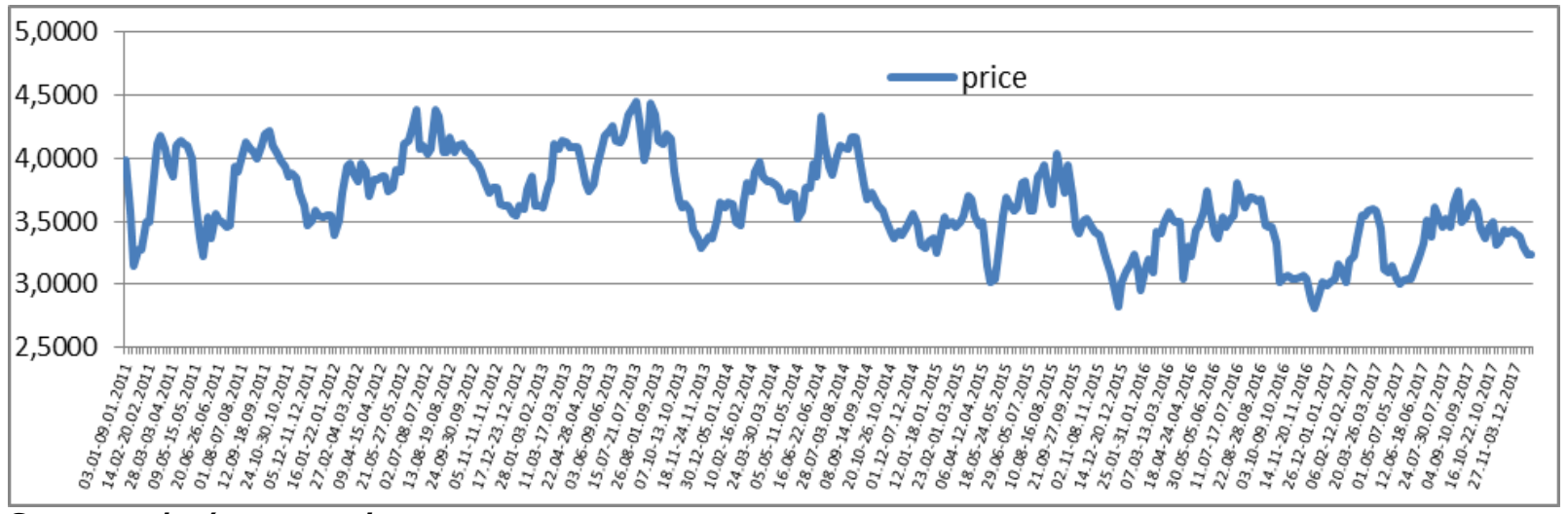

Source: author's presentation

Fig. 5. Weekly average buying-in prices of broiler chickens for 2011-2017 years 
Descriptive statistics of weekly buying-in prices of broiler chickens for 2011-2017 years

\begin{tabular}{|l|l|l|l|l|l|c|c|c|}
\hline Year & mean & median & min & max & range & $\begin{array}{c}\text { Standard } \\
\text { deviation }\end{array}$ & $\begin{array}{c}\text { coefficient } \\
\text { of variation }\end{array}$ & $\begin{array}{c}\text { the average } \\
\text { growth rate }\end{array}$ \\
\hline $\mathbf{2 0 1 1}$ & 3.78 & 3.86 & 3.15 & 4.21 & 1.06 & 0.30 & 7.94 & $-0.235 \%$ \\
\hline $\mathbf{2 0 1 2}$ & 3.86 & 3.89 & 3.39 & 4.38 & 0.99 & 0.23 & 5.96 & $0.038 \%$ \\
\hline $\mathbf{2 0 1 3}$ & 3.91 & 3.99 & 3.29 & 4.45 & 1.16 & 0.33 & 8.44 & $0.005 \%$ \\
\hline $\mathbf{2 0 1 4}$ & 3.73 & 3.72 & 3.29 & 4,33 & 1.04 & 0.24 & 6.43 & $-0.178 \%$ \\
\hline $\mathbf{2 0 1 5}$ & 3.49 & 3.51 & 2.82 & 4.03 & 1.21 & 0.27 & 7.74 & $-0.108 \%$ \\
\hline $\mathbf{2 0 1 6}$ & 3.33 & 3.40 & 2.81 & 3.80 & 0.99 & 0.26 & 7,81 & $-0.076 \%$ \\
\hline $\mathbf{2 0 1 7}$ & 3.35 & 3.38 & 3.00 & 3.74 & 0.74 & 0.21 & 6.27 & $0.152 \%$ \\
\hline
\end{tabular}

Source: author's calculations

In order to check the usefulness of the creeping trend model and the random walk model to predict the purchase prices of broiler chicken, their validity was tested by making forecasts expired for 2011-2017. The study assumes that the length of the verification interval for expired forecasts will amount to 7 years. The ex post error analysis was used to determine the acceptability of forecasts. Comparison of the values forecasted for the past and the real ones observed during this period provided the basis for conclusions on the usefulness of the crawling trend model with fixed segments of linear trends (5, 7, 9 and 11 periods) and the random walk model in forecasting chicken purchase prices. In addition, it made it possible to determine the error rate between forecasts and actual condition. Figure 6 (for smoothing constant $k=5$ ) and figure 7 (for smoothing constant $k=11$ ) presents the real and forecasted prices of chicken purchase. Figure 8 illustrates the actual purchase prices and expired forecasts obtained with the random walk model.

The estimates of the forecast accuracy were made by comparing the data estimated for 20112017 (expired forecast) with actual data from this period and the calculation of ex-post errors. The results of root mean squared error (RMSE), mean absolute error (MAE) and mean absolute percentage error (MAPE) are presented in Table 2.

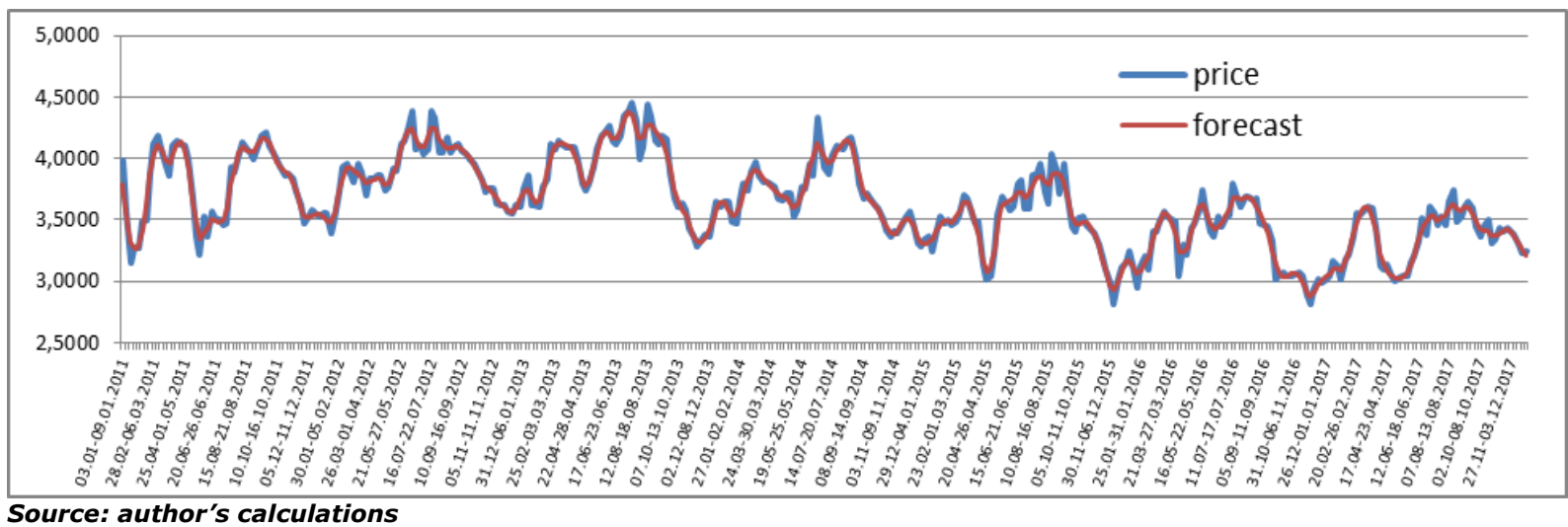

Source: author's calculations

Fig. 6. Real and forecast buying-in prices of broiler chickens - smoothing constant $k=5$ 


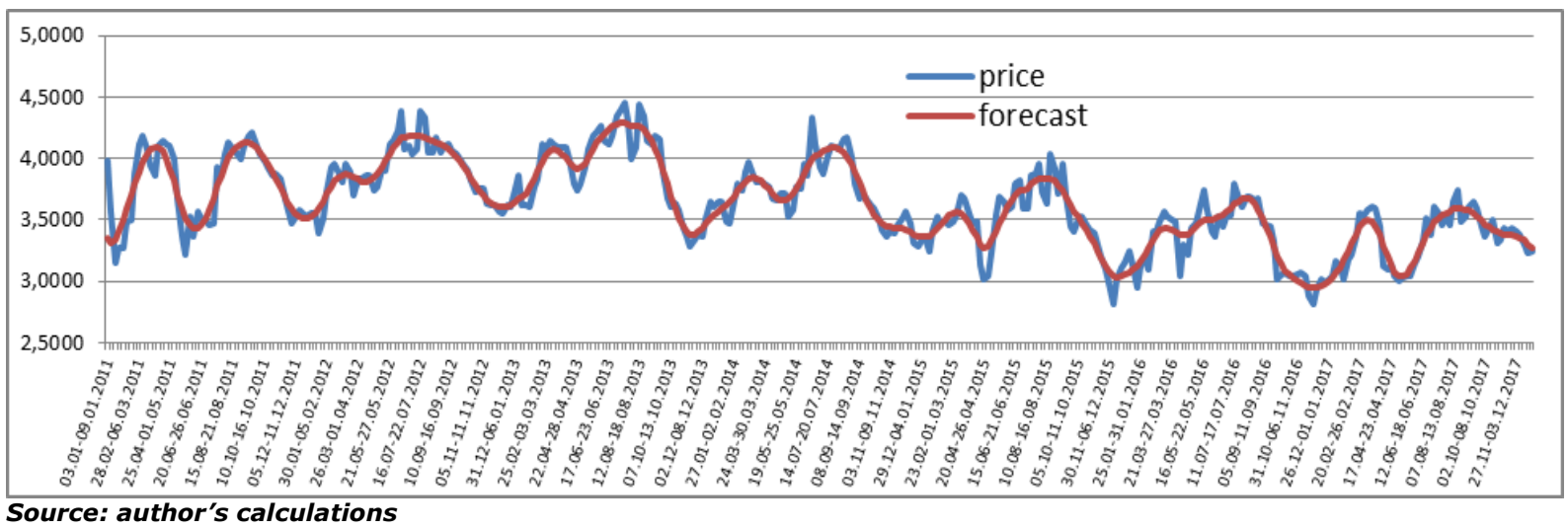

Fig. 7. Real and forecast buying-in prices of broiler chickens - smoothing constant $k=11$

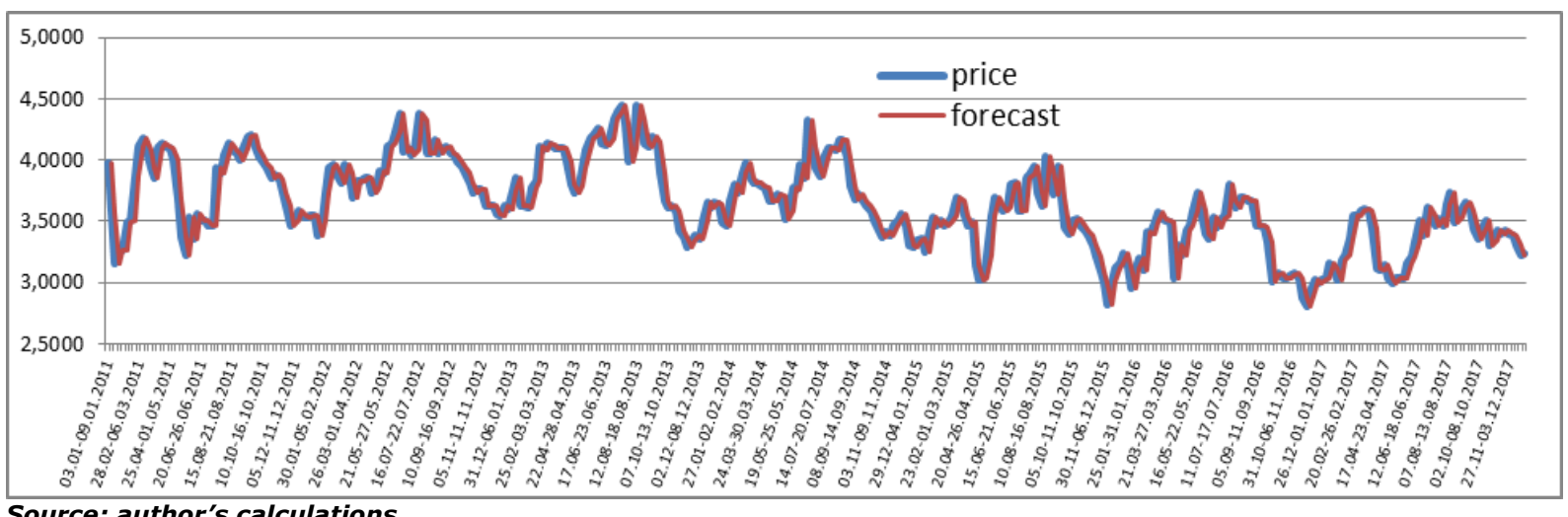

Source: author's calculations

Fig. 8. Real and forecast buying-in prices of broiler chickens - random walk model

Based on figures 6,7 and 8 , it can be concluded that the selected adaptation models are substantively compatible and offer a good fit to the actual data.

Both the crawling trend model and the random walk model with greater weight take into account observations closer to the forecasted values, which worked well in the case of fairly large distortions of random variations in a series of purchase prices for broiler chickens.

Standard deviation values of RMSE forecast errors and absolute MAE errors indicate that the expected chicken purchase prices are close to ideal forecasts. MAPE forecast errors are at a level that allows expired forecasts to be considered acceptable.

Table 2

Values of the different accuracy measures

Source: author's calculations

\begin{tabular}{|l|c|c|c|}
\hline \multicolumn{1}{|c|}{ Forecast model } & RMSE & MAE & MAPE [ \%] \\
\hline Creeping trend model (for $\mathbf{k = 5}$ ) & 0.0598 & 0.0455 & 1.2545 \\
\hline Creeping trend model (for $\mathbf{k}=\mathbf{7}$ ) & 0.0782 & 0.0592 & 1.6265 \\
\hline Creeping trend model (for $\mathbf{k = 9}$ ) & 0.0958 & 0.0726 & 2.0010 \\
\hline Creeping trend model (for $\mathbf{k = 1 1}$ ) & 0.1067 & 0.0817 & 2.2570 \\
\hline Random walk model & 0.1342 & 0.0991 & 2.7387 \\
\hline
\end{tabular}

\section{Conclusions}

Forecasting purchase prices for broiler chicken were carried out using two different approaches: the creeping trend model and the random walk model. The best results, understood as the smallest mean values of relative ex post forecast errors, were obtained for the forecasts determined by the creeping trend model with the shortest segments. Forecast errors increased depending on the 
increase in the value of the smoothing parameter $k$. These results can be explained by high irregularity and busts of the trend.

The presented results should not be treated arbitrarily, because in the case of a different type of time series with a different course, trend slumps and a high share of random variations, better results can be obtained with the help of other models. Reducing the length of the segment in case of large random fluctuations and breakdowns of the trend allows to obtain smaller forecast errors. The effects of using the creeping trend model with linear regression are satisfactory. This model can also be used to predict other phenomena and processes.

\section{Bibliography}

1. Annual Poultry and Poultry Products Report Warsaw Poland, December 2017

2. Borkowski B., Krawiec M., (2009) Ryzyko cenowe na rynku surowcow rolnych, [in:] Nr 148 Zarządzanie ryzykiem cenowym a mozliwosci stabilizowania dochodow producentow rolnych - aspekty poznawcze i aplikacyjne IERiGZ-PIB, p. $47-81$

3. Dudek H., (2005) Prognozowanie cen skupu miesa drobiowego za pomoca sezonowego modelu AMIRA, Stowarzyszenie Ekonomistow Rolnictwa i Agrobiznesu, Roczniki Naukowe T. VII (5) p. $19-25$

4. Dziwulski M., (2017). Industry Monitoring PKO BP, Poultry market, March 2017, http://www.pkobp.pl/media_files/e80dcc1e-7899-4c18-9ca3-16e098faed24.pdf Access:15.02.2018

5. Hamulczuk M. Stanko S. (2009) Prognozowanie cen podstawowych produktow na przykladzie pszenicy i zywca wieprzowego, [in:] Nr 148 Zarzadzanie ryzykiem cenowym a mozliwosci stabilizowania dochodow producentow rolnych - aspekty poznawcze i aplikacyjne IERiGZ-PIB p. $181-208$.

6. Hamulczuk M., (2011). Nr 10 Prognozowanie cen surowcow rolnych z wykorzystaniem modeli szeregow czasowych, Publikacje Programu Wieloletniego 2011-2014, IERiGZ-PIB

7. Hamulczuk M., Stanko S. (2011) Prognozowanie cen surowcow rolnych - uwarunkowania i metody, Komunikaty, raporty, ekspertyzy nr 547, IERiGZ-PIB p. $5-43$

8. Hamulczuk M., Gedek S., Klimkowski C., Stanko S., (2012) Prognozowanie cen surowcow rolnych na podstawie zaleznosci przyczynowych, IERiGZ-PIB, Warszawa

9. Hamulczuk M., Klimkowski C., Stanko S., (2013) Metody ilosciowe w systemie prognozowania cen produktow rolnych,IERiGZ-PIB, Warszawa

10. Livestock and Poultry: World Markets and Trade. USDA Foreign Agricultural Service, April 2017

11. Lira J., (2011) Prognozowanie targowiskowych cen zywca wieprzowego w Polsce. Roczniki Naukowe SERiA XIII (3) p. 168-172

12. Nau R., (2014) Notes on the Random Walk Model, https://people.duke.edu/ rnau/Notes_on_the_random_walk_model--Robert_Nau.pdf Access: 15.02.2018

13. Tluczak A., (2011) Prognozowanie w rolnictwie na podstawie wybranych modeli szeregow czasowych. Wydawnictwo Uniwersytetu Opolskiego, Opole

14. Zelias A. Pawełek B. Wanat S., (2003). Prognozowanie ekonomiczne, PWN, Warszawa. 